\title{
The Will of Flavius Phoibammon
}

In the course of his seven or so years of "exile" in Antinoopolis, the provincial capital of the Thebaid, Dioscorus of Aphrodito, in addition to other writings, generated numerous documents pertinent to Roman private law. Although scholars have studied some of these as individual specimens, his full legal oeuvre from this period of his life - from the late 560s into the early 570s - has never been examined in depth for all it can reveal about his scribal and lawyerly practices. ${ }^{1}$ P.Cair.Masp. II 67151 is an important example of his work. Although its legal technicalities are more complicated than this would suggest, it has been conveniently labeled as "the will of Flavius Phoibammon." By its most important terms, and in a complex dispersal of properties and rights, Phoibammon installs his underage sons as heirs (lines 73-101); leaves by legacy one aroura of vineland with its operating equipment to a monastery (lines 101-160); provides in detail for his own burial (lines 160 - 168); reaffirms his wife's title to his gifts to her at marriage while insisting that she receive nothing from the estate proper (lines 169-182); turns over control of his charitable hospital to his brother (lines 182-195); disinherits other family members (lines 202-222); provides a legal guardian for his sons (lines 225-260); asks an aunt to sell off property in payment of a loan while entitling her to any profits from the transaction (lines 261-274); bequeaths, by a second legacy, to the same monastery, a boat that he has acquired through purchase (lines 275-285); arranges to pay off a debt (lines 285-293); and - finally - provides by a third legacy, until his maturity, annual provisions for a mysterious foster child (lines 294-301).

In P.Cair.Masp. II 67151, Phoibammon's will, with its introductory material and final confirmation, takes over three hundred lines to spell out these dispositions. It is a document for which its editor, Jean Maspero, provided, by his standards, an unusually long introduction and a more than usually detailed commentary, both of which, despite some remaining problems, provide excellent reference points for entering into and understanding the text. That, of course, was more than a century ago. Much more recently, Leslie MacCoull's rhetorical analysis in her famous book on Dioscorus, 1988, and Joëlle Beaucamp's consideration of its legal features in an article dating to 2001 are additional guides. ${ }^{2}$ Apart from these discussions, the extraction of one of its legacies as FIRA III 66 and identification of another passage as referencing Novella 87 on the revocability of bequests, Phoibammon's will has over time not drawn the attention it deserves, perhaps because, as Peter van Minnen once observed, most of Dioscorus's legal compositions had not received full and careful

1 For an elegant survey, however, see van Minnen (2003). See also the studies of Urbanik (2010) and (2012).

2 MacCoull (1988) 50-54; Beaucamp (2001), at 2-7.

https://doi.org/10.1515/9783110683554-010 
translation into a modern vernacular language. ${ }^{3}$ This is no longer the case with P.Cair.Masp. II 67151, thanks to Maria Nowak's 2015 book on Wills in the Roman Empire, where the text is reproduced along with a reliable translation. ${ }^{4}$ This notwithstanding, Phoibammon's will still seems an ideal candidate for testing the rhetorical question posed in my conference abstract:

What better aim for a papyrologist than to recreate as richly as possible, for those expert and not, using all possible clues, the dramatic moment at which the papyrus as a form of paper became a document that entered, however grandly or humbly, the consciousness of history? ${ }^{5}$

In pursuit of that objective, instead of refocusing on the will's terms, as just sketched, I will mainly look to events surrounding its commitment to writing. The procedure will at times employ Robin G. Collingwood's practice of "interpolation," which I interpret to mean, for present purposes, the imaginative construction of what must have happened as this is implied by the fixed nodes of fact provided by the document itself. ${ }^{6}$ In attempting this I will refrain from good Buddhist practice that would insist on going back to the plant itself, that life form which, after human intervention, would give to Phoibammon's will its material substratum. It is enough to say that papyrus was one of the mediums named in Justinian's Institutes (2.10.12) as approved for receiving the texts of wills: "it does not matter [says the Institutes] whether a will is made on tablets or papyri or parchments or some other material."7 Obviously, Phoibammon's will as written on P.Cair.Masp. II 67151 fulfills this loose requirement at the same time as it raises questions about how Dioscorus acquired blank papyrus for his office use, at what cost, and how this influenced what these days would be called the "transaction costs" of his business with Phoibammon and his other clients - if clients is not too anachronistic a term for those who sought his services. He presumably kept records of office expenses, now lost, with entries for the purchase of papyrus rolls for use in drafting documents, some of them later reused for some of his poems. ${ }^{8}$

An immediate complication is that Phoibammon's will survives in two copies. The already mentioned P.Cair.Masp. II 67151 measures nearly 14 feet in length by a bit over a foot in width, or $31.5 \mathrm{~cm}$ to be more exact; its near twin, 67152, is not quite eight feet long and again, just a bit over a foot wide, or $30.3 \mathrm{~cm}$ to be more

3 Legacy: FIRA III 66, reproducing lines 101-160, with Latin translation; Novella 87: Amelotti/Migliardi Zingale (1985') 67-68 (no. 22), reproducing lines 124-130; need for translations: van Minnen (2003) 125.

4 Nowak (2015): text, p. 420 - 427; translation, p. 427-433.

5 This question is also at the core of Keenan (forthcoming b).

6 Collingwood (1994) 231-249.

7 Nihil autem interest, testamentum in tabulis an in chartis membranisve vel in alia materia fiat. This freedom of choice had a long history; cf. P.Oxy. XXXVIII 2857.21-24 of 134 CE ("tablets, codicils, papyrus, or any other medium").

8 Oblique backing for such a presumption: Haensch (2015). 
exact. Both widths correspond to the standard roll widths of the period, but differ enough to show they are not from the same roll. ${ }^{9}$ Maspero's silence on the matter suggests that their versos are blank, which seems strangely wasteful if these rolls with their fully inscribed rectos were brought to Aphrodito from Antinoopolis for Dioscorus's later use. ${ }^{10}$ Possibly explanatory is that Phoibammon's will, dated 15 November 570, is the last datable document attributed to Dioscorus, 67152, the last one assignable to his hand. Perhaps he never got around to using their empty sides. ${ }^{11}$

Returning to that 15 November 570 date, we can try to enter the space where the will was drafted and imagine the drama surrounding its composition, the moment when the message, the text of Phoibammon's will, met its medium, in the form of the smaller of the two grand sheets of papyrus (67152). The evidence is slight but suggestive. In its own words, the will claims to have been composed in a demosios kai praktikos topos, perhaps best translated generically as "a public place of business."12 Maspero himself was certain the phrase indicated the office of the civil governor (praeses) of the (Lower) Thebaid. ${ }^{13}$ Presumably this was in or near "the forum of the Thebaid" (phoron Thēbaidos), evidenced in other documents, the hub of provincial legal activity in Antinoopolis, an obvious place of convergence for lawyers (scholastici, synegoroi) and bureaucrats. ${ }^{14}$ Note also, unless this is just a figure of speech, that Phoibammon himself speaks of his own active life in terms of "walking in the agora," the Greek equivalent of the Latin forum. ${ }^{15}$

Under ordinary circumstances, we would expect an effort on the part of the testator to effect on this occasion a dramaturgical as well as a legal success, the latter mostly dependent on his legal advisor, the former on himself. ${ }^{16}$ The very existence of the will assures the presence of at least two parties: first, of course, the testator, Phoibammon; second, Dioscorus himself.

To take Phoibammon first: he was a salaried chief doctor, presumably therefore in charge of other doctors. The son and successor to a chief doctor now deceased, he was an overseer and owner of a charity hospital inherited from his father. A property owner both by inheritance and personal acquisition, his holdings included agricultural land together with ownership of the capital equipment needed to work it. He was a speaker of Greek, with a claim to literacy, at least as far as signature literacy

9 CPR XXX introd., 31-40.

10 In any case, the versos were never photographed by Adam Bülow-Jacobsen during his work at the Egyptian Museum in Cairo, and it looks as if P.Cair.Masp. II 67152 was pasted to cardboard before being glassed (observation thanks to Jean-Luc Fournet, email 10 July 2017).

11 Though still alive in 573: P.Cair.Masp. I 67096.7-9.

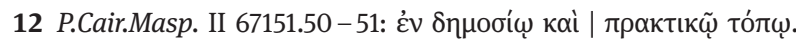

13 "sans doute": P.Cair.Masp. II 67151 introd., p. 85.

14 Forum of the Thebaid: P.Ant. II 104.1; P.Cair.Masp. III 67312.7; P.Lond. III 992.13; P.Lond. V 1707.6; P.Stras. I 40.6. Convergence: cf. P.Oxy. LXIII 4394.19-31 and 4398.6-11.

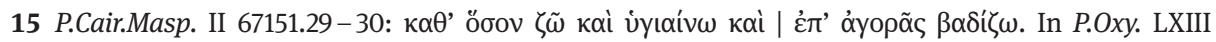
4398.7 the forum seems rather to have been a part of the agora.

16 Goffman (1959). 
is concerned, and probably beyond. ${ }^{17}$ He was presently sound of mind and body but contemplating death's inevitability in sententious terms. As the will's preamble proclaims, "The end of all things, including the race of mortals, is death, and this it is utterly impossible to escape; but for those who are thoughtful, to think ahead and prepare for it is the most blessed of all things."18 Thoughtful and responsible, Phoibammon had married a virgin bride, now his "most nobly born" wife, ${ }^{19}$ who had borne him sons, to an uncertain number. They are much loved, ${ }^{20}$ and very young, ${ }^{21}$ young enough to require a guardian should their father die prematurely. Phoibammon and his wife may therefore themselves have been relatively young in 570. And finally, if some of the will's language can be taken as meaningful, that is, not just formulaic, he was a man of religious sentiment and conviction, concerned for his soul's salvation; he was, in any case, actively and provably involved with the local monastery and its leading monks.

The other principal to Phoibammon's will, Dioscorus, was probably in his midforties if not pushing fifty. In addition to other documents credited to him as a legal expert, he is generally considered the "author" of Phoibammon's will - but the issue is not quite so simple. This is because a third party, an anonymous, comes into play, he being the one responsible for the more complete, and fully edited, of the two surviving versions, the one now numbered 67151. The unedited version numbered 67152, Maspero assigned "nearly certainly" ("presque certainement”) to the hand of Dioscorus, based on its similarity to that on page 3 of P.Cair.Masp. I 67002, part of the grand but infuriating complaint to the duke of the Thebaid, framed in the first person plural in behalf of the aggrieved villagers of Aphrodito. ${ }^{22}$ Because the abbreviations in 67152 are resolved in 67151, and because the superlinear and marginal insertions of 67152 are copied properly into and onto the lines of 67151 , 67152 is accepted as the (incomplete) draft version of the will; 67151, despite various minor mistakes, is the fair copy.

The online images reveal that the anonymous's hand is after all - though perhaps only to my eye - the more elegant of the two, closer to the ideals of the Byzantine chancery style, while the survival of a protocol at the start of the roll on which 67151 was written would seem to clinch its claim to be the authoritative or definitive text. This conclusion, however, is undercut by Maspero's suspicions that this protocol was cut away from another document and glued to the top of 67151, a practice

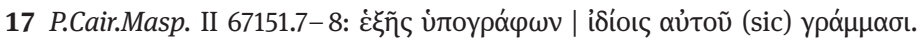

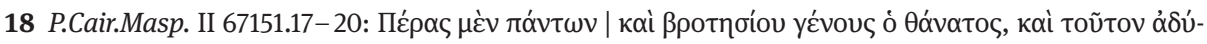

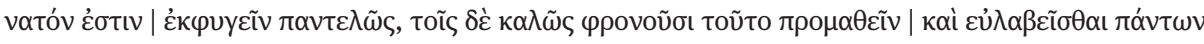

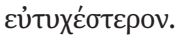

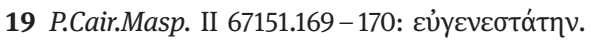

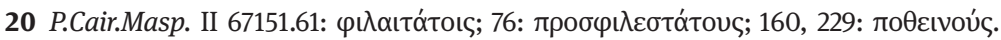

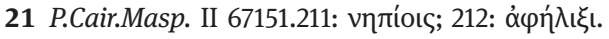

22 Keenan (2008). 
described in Novella 44.2 as a troublesome source of forgeries. ${ }^{23}$ In any case, I think we can conclude that the anonymous need not have been present at the drafting of Phoibammon's will. He copied it later on, laboriously moving from eye to hand and back, rather than from dictation. Whether he was responsible for the pasting on of the alien protocol is indeterminable.

As far as copies are concerned, observe that Justinian in his Institutes (2.10.13) approves the making of extra ones for wills, as long as they all follow the rules, noting especially the case of the testator about to travel by sea ("navigaturus") and wanting to have copies both with him on his travels and safely preserved back home. "But [continues the emperor, in the Birks-McLeod translation] all kinds of pressures can suggest the same precautions." ${ }^{24}$ I take this passage as implying the dangers of travel by sea, the transprovincial scope of Roman law, and the chance of a will's having more than one authoritative written version.

Returning to Dioscorus's "office," we see that, according to the custom of the times, Dioscorus on 15 November 570 and the anonymous later on used their rolls transversa charta, rotating them 90 degrees clockwise and writing top down from the former left edges of their rolls. The practice, though requiring that writing proceed across the fibers, was certainly advantageous from planning and layout points of view, and possibly also from the economic. The results, as here, can be texts of many lines, each, however, being relatively short in terms of word count because Byzantine documentary writing tends to be so large.

Phoibammon presents himself as having dictated his will "in Greek words" and as having ordered it to be written down "in [Greek] letters," 25 a claim seemingly at odds with MacCoull's presentation of Dioscorus as having in Phoibammon's will "produced his longest and most elaborate prose composition" (my stress). ${ }^{26}$ I say this because Phoibammon after all is the legal actor, a fact that gives him a claim to be, or at least deemed to be, the author of his own will. This is a claim reinforced by the use of what philosopher John L. Austin classified as "performative present tenses," notable, for Phoibammon's will, in the first person singular verbs that

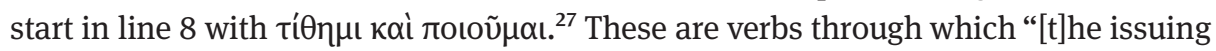

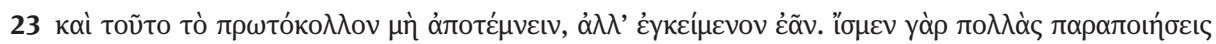

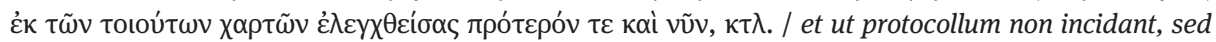
insertum relinquant. Novimus enim multas falsitates ex talibus chartis ostensas et prius et nunc, etc. See Migliardi Zingale (1982) 1-25 (12-14 for P.Cair.Masp. II 67151). In general on forgery in the papyri: Fournet (2016).

24 Sed et unum testamentum pluribus codicibus conficere quis potest, secundum optinentem tamen observationem omnibus factis. Quod interdum et necessarium est, si quis navigaturus et secum ferre et domi relinquere iudiciorum suorum contestationem velit, vel propter alias innumerabiles causas, quae humanis necessitatibus imminent.

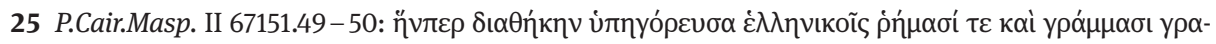

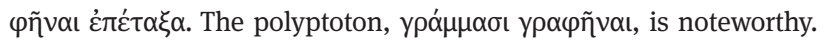

26 MacCoull (1988) 50.

27 Austin $\left(1962^{2}\right)$ passim. 
of the utterance is [equivalent to] the performing of an action," verbs, that is, which invest a document with performative power, as last wills and testaments traditionally do. ${ }^{28}$

The process of putting into written form an oral act like Phoibammon's will must have been cumbersome, complicated, and time-consuming. And now, as presented here, it emerges, not as the product of a single author, but as a collaborative effort with dual voices - the testator's and the legal expert's. To these we might add a third by crediting the prolix "byzantinische Urkundenstil” itself with contributing to the formulation of the text, or even a fourth because of its inclusion of verbatim references to Justinian's legal works, or even a fifth if the preamble on human mortality (lines 17-20) was drawn from a collection of such preambles. ${ }^{29}$ Dioscorus' personal voice, proof of his compositional literacy, can perhaps be seen in his adaptations of the testamentary template and in his creative diction, his use of words that

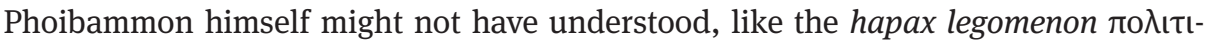

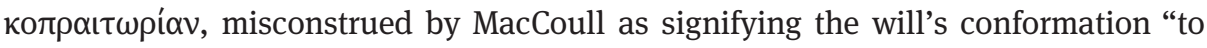
the requirements of the city praetorium," but rightly seen by Maspero, Beaucamp, and Nowak as signifying the melding of ius civile (лолıтเко-, civil law) and ius hon-

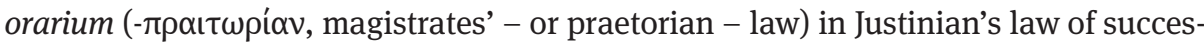
sion. ${ }^{30}$ Phoibammon's own voice can perhaps be distinguished in his repeatedly expressed preemptive concerns for possible challenges to the interests of his heirs, his beloved underage sons; his claims of modest means despite landed interests in two locations and a 60-solidus annual salary; and the clearly stated religious motivation behind some of his testamentary arrangements. He of course must be the one supplying the "metadata" for incorporation into the documentary template, but in this regard three blank spaces catch the eye. In ascending order of importance, they are to be found at:

1. Line 153, where the number of the coming ( $\mu \varepsilon \lambda \lambda$ oúons) indiction and the word for indiction itself are lacking though the will's dating clause, lines 3-4, firmly

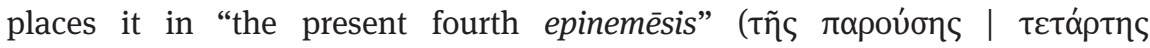

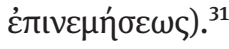

2. Lines 261-274, which give business instructions to the apparent financial benefit of an aunt whose name is left blank in line $261 .^{32}$

3. Lines $76-77$, which appoint Phoibammon's sons as heirs without naming them. ${ }^{33}$

28 Austin (1962²) 6-7 (quote); Tiersma (2010) esp. 36-40.

29 Fournet (2013) 143-144.

30 P.Cair.Masp. II 67151.44; MacCoull (1988) 50; Maspero, note ad loc.; Beaucamp (2001) 3; Nowak (2015) 420 - 433; Just. Inst. 2.10.2-3: coepit in unam consonantiam ius civile et praetorium iungi.

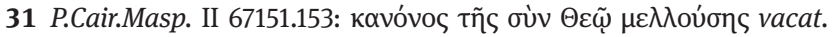

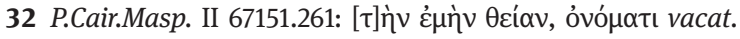

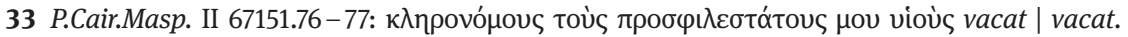


The first two blanks resist certain explanation, but the reason for the third, as has been pointed out, ${ }^{34}$ may be provided by Justinian's Institutes, expressing a rule insisting, in accordance with an imperial constitution of 531, that to guarantee the "sincerity" (sinceritas) of a will and prevent fraud, heirs' names must be entered either by the hand of the testator himself or his witnesses. ${ }^{35}$ Presumably the witnesses would perform this function only if the testator himself was illiterate or otherwise incapable.

Toward the beginning, Phoibammon indicates he will subscribe in his own letters, but his signature is lacking at the end. ${ }^{36}$ Likewise missing are the signatures of the witnesses although they are introduced in precise legal form as having been summoned, seven in number, "Roman citizens and ephebes, ... coming together at one meeting and time, with no other business intervening," and ready to sign. ${ }^{37}$ Contrary to MacCoull, who treats ephēboi as indicating "those of the gymnasium," the Latin equivalents from the Institutes (2.10.1) and Code (CJ 6.23.21) show that these citizens, simply put, are puberes, i.e., of legal age. The question then is not, as MacCoull would have had it, about sixth-century "analogues" to the classical gymnasium, but the content of Roman citizenship three and a half centuries after the Antonine Constitution. ${ }^{38}$

It was of course the testator's responsibility to convoke (rogare) his witnesses - a gathering of men - but it seems this never happened in Phoibammon's case. The absence of their names is a serious loss for what they might have told about society in Antinoopolis in 570 and the "network" within which Phoibammon functioned, probably filled with members of the middling "Flaviate," perhaps with useful prosopographical links and further elaboration on what is already known about Dioscorus's own networks in the provincial capital. ${ }^{39}$ Not only did the witnesses not sign; they never affixed their seals, a point doubly made in the text, which claims itself to be

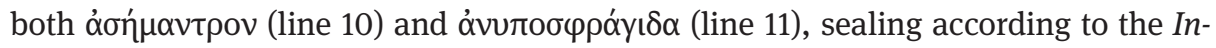
stitutes (2.10.3) being a requirement of the ius honorarium, not of the ius civile. ${ }^{40}$

Without signatures or seals, it is impossible to prove that the witnesses were present when Phoibammon dictated his will, and so it appears from this and other signs that neither 67151 nor 67152 can be considered an authoritative or definitive version.

34 Beaucamp (2001) 6.

35 Just. Inst. 2.10.4, cf. CJ 6.23.29.pr: Sed his omnibus ex nostra constitutione propter testamentorum sinceritatem, ut nulla fraus adhibeatur, hoc additum est, ut per manum testatoris vel testium nomen heredis exprimatur et omnia secundum illius constitutionis tenorem procedant.

36 P.Cair.Masp. II 67151.7-8. See above with n. 17.

37 P.Cair.Masp. II 67151.44-49.

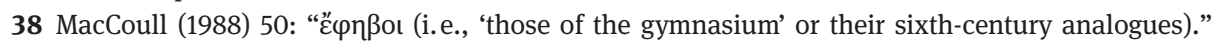
But see, e.g., Just. Inst. 2.10.1: civibus Romanis puberibus, and CJ 6.23.21: [rogatis testibus] septem numero, civibus Romanis, puberibus. Maspero had from the start gotten this right: "majeures" (P.Cair.Masp. II 67151 introd., p. 85).

39 For now, see Worp (2008).

40 ex edicto praetoris signacula testamentis imponerentur. 
They are a draft (67152), perhaps even a "pre-draft," and its copy (67151) that were never put to use, among the scrap paper Dioscorus brought home from Antinoopolis after clearing out his office - a puzzling waste and a serious obstacle to the project of reconstruction this paper announced at its start. We can only presume that Phoibammon himself took his own authoritative copy away from Dioscorus's office with blanks filled and signatures entered. This authoritative version would accordingly fall into the category of what I have elsewhere called "known unknowns," lost documents whose existence can be conjectured or assumed, whose form and contents can be imagined and reconstructed, sometimes, as here, nearly word for word. ${ }^{41}$

Meanwhile, P.Cair.Masp. II 67151 and 67152, whatever their statuses, if we combine MacCoull's and Beaucamp's presentations of them, suggest a provincial Egyptian capital alert to and respectful of Roman imperial law, immersed in the rhetoric of its day, stable in its secular institutions, devout in its Christianity, free from the disruptions evidenced for the village to which Dioscorus was about to return - in sum, and ironically, a highly cultured environment with no hint of the regime change looming three generations hence. ${ }^{42}$ The process of that change, owing to the current high interest in Late Antiquity and advances in Coptic and Arabic papyrology, has become a central problem of historical papyrology, a problem to whose timely treatment this conference has been commendably dedicated.

\section{Bibliography}

Amelotti/Migliardi Zingale $\left(1985^{2}\right)$ : Mario Amelotti and Livia Migliardi Zingale, Le costituzioni giustianee nei papiri e nelle epigrafi (Legum lustiniani imperatoris vocabularium 1), Milan. Austin (1962 $2^{2}$ : John L. Austin, How to Do Things with Words, Cambridge, MA.

Beaucamp (2001): Joëlle Beaucamp, "La transmission du patrimoine. Législation de Justinien et pratiques observables dans les papyrus," in: Subseciva Groningana 7, 1-13.

Beaucamp (2007): Joëlle Beaucamp, "Byzantine Egypt and imperial law," in: Roger S. Bagnall (ed.), Egypt in the Byzantine World 300-700, Cambridge, 271-287.

Collingwood (1994): Robin G. Collingwood, The Idea of History, rev. ed., Oxford.

Fournet (2013): Jean-Luc Fournet, “Culture grecque et document dans l'Égypte de l'antiquité tardive," in: Journal of Juristic Papyrology 43, 135-162.

Fournet (2016): Jean-Luc Fournet, "Le faux en écriture d'après la documentation papyrologique," in: Comptes-rendus des séances de l'Académie des inscriptions et belles lettres 1 (JanuaryMarch), 67-90.

Goffman (1959): Erving Goffman, The Presentation of Self in Everyday Life, New York.

Haensch (2015): Rudolf Haensch, "From free to fee? Judicial fees and other litigation costs during the High Empire and Late Antiquity," in: Dennis Kehoe, David M. Ratzan, and Uri Yiftach (eds.), Law and Transaction Costs in the Ancient Economy (Law and Society in the Ancient World), Ann Arbor, 253-272.

41 Keenan (forthcoming a).

42 For law in particular, see Beaucamp (2007). In general, I here in essence reproduce the sentiments of MacCoull (1988). 
Keenan (2008): James G. Keenan, “'Tormented voices’. P.Cair.Masp. I 67002,” in: Jean-Luc Fournet and Caroline Magdelaine (eds.), Les archives de Dioscore d'Aphrodité cent ans après leur découverte. Histoire et culture dans l'Égypte Byzantine. Actes du colloque de Strasbourg (8-10 décembre 2005) (Collections de l'Université Marc Bloch - Strasbourg; Études d'archéologie et d'histoire ancienne), Paris, 171-180.

Keenan (forthcoming a): James G. Keenan, "Known unknowns. Thoughts on lost (papyrus) evidence," in: Comparative Studies in Ancient Bureaucracy and Officialdom. $5^{\text {th }}$ International Conference of the Research Network "Imperium and Officium", Vienna, 6-8 November 2014 (forthcoming).

Keenan (forthcoming b): James G. Keenan, "Papyri tell tales. Creating narratives from documents," BASP (forthcoming).

MacCoull (1988): Leslie S. B. MacCoull, Dioscorus of Aphrodito. His Work and His World (The Transformation of the Classical Heritage 16), Berkeley, Los Angeles, and London.

Migliardi Zingale (1982): Livia Migliardi Zingale, "In margine a Nov. lust. 44.2: TO KA^OYMENON

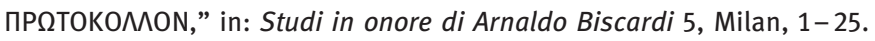

Nowak (2015): Maria Nowak, Wills in the Roman Empire. A Documentary Approach (The Journal of Juristic Papyrology. Supplement XXIII), Warsaw.

Tiersma (2010): Peter M. Tiersma, Parchment, Paper, and Pixels. Law and the Technologies of Communication, Chicago.

Urbanik (2010): Jakub Urbanik, "P.Cairo Masp. I 67120 and the liability for latent defects in late antique slave sales or back to epaphe," in: Journal of Juristic Papyrology 40, 219-247.

Urbanik (2012): Jakub Urbanik, "Diligent carpenters in Dioskoros' papyri and the Justinianic (?) standard of diligence. On P.Cairo Masp. II 67158 and 67159," in: Jakub Urbanik (ed.), Culpa. Facets of Liability in Ancient Legal Theory and Practice. Proceedings of the Seminar Held in Warsaw 17-19 February 2011, Warsaw, 273-296.

Van Minnen (2003): Peter van Minnen, "Dioscorus and the Law," in: Alasdair A. MacDonald et al. (eds.), Learned Antiquity. Scholarship and Society in the Near-East, the Graeco-Roman World, and the Early Medieval West (Groningen Studies in Cultural Change 5), Leuven, Paris, and Dudley, MA, 115-133.

Worp (2008): Klaas A. Worp, "Witness subscriptions in documents from the Dioscorus archive," in: Jean-Luc Fournet and Caroline Magdelaine (eds.), Les archives de Dioscore d'Aphrodité cent ans après leur découverte. Histoire et culture dans l'Égypte Byzantine. Actes du colloque de Strasbourg (8-10 décembre 2005) (Collections de l'Université Marc Bloch - Strasbourg; Études d'archéologie et d'histoire ancienne), Paris, 143-153. 
